\title{
CREATIVE THINKING WITH STEM-BASED PROJECT-BASED LEARNING MODEL IN ELEMENTARY MATHEMATICS LEARNING
}

Submitted:

18 Desember 2021

Accepted:

5 Januari 2021

Published:

31 Januari 2022

\author{
Nora Surmilasari*1, Arita Marini ${ }^{2}$, Herlina Usman ${ }^{3}$ \\ norasurmilasari@univpgri-palembang.ac.id ${ }^{1}$ \\ aritamarini@unj.ac.id ${ }^{2}$ herlina@unj.ac.id ${ }^{3}$ \\ Universitas PGRI Palembang ${ }^{1}$ \\ Universitas Negeri Jakarta ${ }^{2,3}$
}

*Corresponding Author

\begin{abstract}
Entering the era of Industrial Revolution 5.0, changes occurred in all aspects, including education. One of the important competencies in this era is the ability to think creatively. In addition, students are also required to be able to integrate their knowledge with science, technology, engineering, and mathematics (STEM). This research is a quasi-experimental research with a non-equivalent post-test only control group design which aims to determine whether is there an effect of using the Project-Based Learning model with STEM-based

approach on the creative thinking skills of elementary school students in class $\mathrm{V}$ mathematics. The population in This research is the fifth-grade students of SDN 225 Palembang. As for the research sample for the experimental class, students of class V-A and the control class, students in class V-B. The experimental class was treated with Project-Based Learning based on STEM, while the control class used the Project-Based Learning model only. Data collection techniques using tests and data analysis with $\mathrm{t}$ test. Based on the analysis of research data with a significant value of $0.006<0.05$, it can be concluded that there is an effect of students' creative thinking skills using the STEM-based Project-Based Learning learning model in Mathematics Learning for fifthgrade elementary school.
\end{abstract}

Keywords: Project-Based Learning, STEM, Creative Thinking, Elementary Mathematics

\section{INTRODUCTION}

In the Industrial Revolution 5.0 era, changes occurred in various aspects quickly and continuously. This dynamic change requires students to have creative thinking skills, non-routine thinking skills and have new ideas in dealing with every problem. One of the competencies that students must have to adapt to dynamic changes is the ability to think creatively (Widana, 2020). Mathematics learning that is integrated with science and technology can train students' creative thinking skills. Because learning mathematics, 
which is characterized by reasoning and logical thinking, can underlie students' creative thinking abilities.

Contextual-based mathematics learning can connect abstract mathematical concepts with concrete concepts that exist in everyday life so that learning becomes more meaningful (Sudiarta and Widana, 2019). The beginning of contextual learning to solve contextual problems is by mathematical modeling, which is changing the context of the problem into a mathematical model. This mathematical modeling can be completed quickly and efficiently by using information technology (Nafiah and Suyanto, 2014). The integration between learning mathematics, science, technology, and engineering is known as the STEM (Science, Technology, Engineering, Mathematics) approach.

Based on the results of PISA, the creative thinking ability of Indonesian students is very low. Judging from the ability of students to solve contextual problems in learning mathematics is low (Nilasari \& Anggreini, 2019). The research results of Mawardhiah and Manoy (2018) concluded that the creative thinking ability of students was very low. In the analysis, the selection of the right learning model can develop students' creative thinking skills. So that student are not emphasized in mastering theoretical mathematics but creative mathematics.

The foresight and creativity of educators in choosing and combining learning models that are following the characteristics of learning, the characteristics of students, and the competencies demanded by the industrial revolution 5.0 absolutely must be mastered. Currently, the learning model must be combined with technology which is also growing rapidly. According to Hidayat, et al (2019), the learning model must involve the intellectual and emotional aspects of students simultaneously. The learning model must also be able to analyze, shape attitudes, and make students actively involved in learning.

One of the learning models that combines the intellectual and emotional involvement of students is the Project-Based Learning (PBL) model. The PBL learning model focuses on the intellectual mentality of students to think creatively in solving problems (Redkar, 2012). In the learning process with the PBL model, the teacher acts as a facilitator. Learners fully get the opportunity to use their ideas and thoughts in solving contextual problems so that they can form new concepts in learning (Zhou, 2012).

In elementary school mathematics learning, the PBL learning model can be combined with the STEM approach. According to Carlisle and Weaver, 2018; Association 
of American Universities, 2013) Mathematics learning using the STEM approach has advantages, including: (1) in education, the boundaries of science, technology, engineering, and mathematics lessons can be eliminated; (2) scientific literacy skills and abilities can be improved; (3) 21st-century competencies which include communication skills, creative thinking collaboration and developing creativity can be developed; (4) problem solutions can be simplified through technology and engineering; (5) can develop contextual problem-solving skills.

Learning research using the PBL model has attracted the attention of educators and education observers. Wahyu, R, 2016; Kristanti, et al, 2016) have applied the PBL model in learning and concluded that the application of the PBL model can improve student learning outcomes. Aldabbus, S (2018) researched the implementation and challenges of implementing PBL by elementary school teachers. Chiang and Lee (2016) also conducted a similar study to find out whether there was an effect of implementing the PBL model on problem-solving abilities and students' learning motivation. Melda Arianti (2017) researched the effectiveness of PBL in learning. In the research conducted, the researcher also used the PBL model but combined it with the STEM approach.

Based on the background and literature review above, the formulation of the problem in this research is whether is there an effect of using the STEM-based PBL learning model on students' creative thinking skills in mathematics learning in fifth-grade elementary school. The hypothesis in this study is that there is a significant effect of using the STEM-based PBL learning model on the creative thinking ability of students in mathematics learning in fifth-grade elementary school.

\section{METHOD}

This research is an experimental study with a non-equivalent post-test only control group design. The research population is the fifth-grade students of SDN 225 Palembang for the 2020/2021 academic year. The research sample was determined by using a random sampling technique. Class V-A is the experimental class and V-C is the control class. There were 33 students in the experimental class consisting of 20 girls and 13 boys. While the students in the control class were 32 people consisting of 19 girls and 13 boys. Between the experimental class and control class got different treatments. STEM-based PBL learning by utilizing information technology in the form of internet 
use and educational game applications. The control class was given the usual PBL learning treatment.

PBL learning has specific steps in its implementation, they are (1) learning starts from essential questions. Questions must be answered by doing activities; (2) designing project activity steps; (3) making a schedule in completing the project; (4) Monitoring project developments and student activities; (5) assessing and conducting discussions on project achievements and student activities; (6) evaluation and reflection. At the end of the project, students will present the project results and discuss to obtain new findings (new inquiry) as answers to questions and problems posed at the beginning of learning.

The technique of collecting data on creative thinking skills is by using a written test and then analyzing creative thinking skills based on indicators of creative thinking abilities. Of the 20 questions tested, 17 questions were declared valid with reliability of 0.706. Of the 17 questions that were declared valid, 10 questions were chosen that represent each indicator of the fractional material. The validity of the research instrument was tested with Pearson's product-moment correlation test and the reliability test with Croncbach's Alpha. After testing the research instrument, then the instrument that is declared valid and reliable is used for research. After the control and experimental classes were given treatment, a creative thinking ability test was conducted. The research data were analyzed by an independent sample t-test. The test was carried out after the prerequisites for the research data were carried out, namely normality and homogeneity tests.

\section{RESULTS}

The experimental class was treated with STEM-based PBL learning while the control class was given PBL learning treatment. After being treated, descriptive statistical data from the two classes were obtained as follows: 
Table 1. Research Result Data

\begin{tabular}{|c|c|r|r|r|r|}
\hline & Class & $\mathrm{N}$ & mean & Std. Deviation & Std. Error Mean \\
\hline \multirow{2}{*}{$\begin{array}{c}\text { Math } \\
\text { score }\end{array}$} & Experiment & 33 & 80.24 & 8.617 & 1,500 \\
\cline { 2 - 6 } & Control & 32 & 72.94 & 11.862 & 2,097 \\
\hline
\end{tabular}

The number of samples of the experimental class is 33 and the control class is 32. The average of the experimental class is 80.24 and the average of the control class is 72.94. To test the similarity of the two averages between the experimental and control groups, a t-test was performed with the condition that both groups of data were normally distributed and homogeneous. The following are the results of normality testing of the experimental and control classes using the Kolmogorov-Smirnov IBM SPSS 25 test.

Table 2. Normality Test One-Sample Kolmogorov-Smirnov Test

\begin{tabular}{|c|c|r|}
\hline \multicolumn{2}{|c|}{} & \multicolumn{2}{c|}{ Math score } \\
\hline \multirow{2}{*}{ Normal Parameters, b } & mean & 65 \\
\cline { 2 - 4 } & Std. Deviation & 76.65 \\
\hline \multirow{2}{*}{ Most Extreme Differences } & Absolute & 10,901 \\
\cline { 2 - 4 } & Positive & .098 \\
\cline { 2 - 4 } & negative & .098 \\
\hline \multicolumn{2}{|c|}{ Test Statistics } & -.071 \\
\hline \multicolumn{2}{|c|}{ Asymp. Sig. (2-tailed) } & .098 \\
\hline
\end{tabular}

Based on the results of calculations with SPSS, the significance value for the normality test for the two groups of experimental and control data groups was $0.197>$ 0.05 . So it can be concluded that data from the test results of students' creative thinking skills in the experimental class and control class are normally distributed. After being declared normal, it is continued with the homogeneity test as a prerequisite test before carrying out the t-test. The results of the homogeneity test are shown in table 3 below:

Table 3. Homogeneity Test Results 


\begin{tabular}{|c|c|r|r|r|r|}
\hline \multicolumn{2}{|c|}{} & \multicolumn{1}{c|}{$\begin{array}{c}\text { Levene } \\
\text { Statistics }\end{array}$} & \multicolumn{1}{c|}{ df1 } & \multicolumn{1}{c|}{ df2 } & \multicolumn{1}{c|}{ Sig. } \\
\hline \multirow{3}{*}{$\begin{array}{c}\text { Math } \\
\text { score }\end{array}$} & Based on Mean & 1,702 & 1 & 63 & .197 \\
\cline { 2 - 6 } & Based on Median & 1.007 & 1 & 63 & .319 \\
\cline { 2 - 6 } & $\begin{array}{c}\text { Based on Median and with } \\
\text { adjusted df }\end{array}$ & 1.007 & 1 & 50,444 & .320 \\
\cline { 2 - 6 } & Based on trimmed mean & 1,800 & 1 & 63 & .185 \\
\hline
\end{tabular}

Based on table 3, it can be seen that the significance value for the homogeneity test of the two groups of experimental and control data is $0.197>0.05$ so it can be concluded that the two groups of data come from the same variance or they are homogeneous. After the prerequisite test was carried out, and the data was declared normal and homogeneous, it was continued with the independent sample t-test to answer the research hypothesis. The t-test was carried out with the help of IBM SPSS 25 with the following output:

Table 4. Results of Independent Samples Test

\begin{tabular}{|c|c|c|c|c|c|c|c|c|c|c|}
\hline & \multicolumn{2}{|c|}{$\begin{array}{l}\text { Levene's } \\
\text { Test for } \\
\text { Equality of } \\
\text { Variances }\end{array}$} & \multicolumn{7}{|c|}{ t-test for Equality of Means } \\
\hline & & \multirow[b]{2}{*}{$\mathrm{F}$} & \multirow[b]{2}{*}{ Sig. } & \multirow[b]{2}{*}{$\mathrm{t}$} & \multirow[b]{2}{*}{$\mathrm{df}$} & \multirow{2}{*}{$\begin{array}{l}\text { Sig. (2- } \\
\text { tailed) }\end{array}$} & \multirow{2}{*}{$\begin{array}{c}\text { Mean } \\
\text { Differen } \\
\text { ce } \\
\end{array}$} & \multirow{2}{*}{$\begin{array}{c}\text { Std. Error } \\
\text { Differenc } \\
\mathrm{e}\end{array}$} & \multicolumn{2}{|c|}{$\begin{array}{c}95 \% \\
\text { Confidence } \\
\text { Interval of the } \\
\text { Difference }\end{array}$} \\
\hline & & & & & & & & & Lower & Upper \\
\hline \multirow{2}{*}{$\begin{array}{c}\text { Mat } \\
\mathrm{h} \\
\text { scor } \\
\mathrm{e}\end{array}$} & $\begin{array}{c}\text { Equal } \\
\text { variances } \\
\text { assumed }\end{array}$ & $\begin{array}{r}1,70 \\
2\end{array}$ & .197 & $\begin{array}{r}2.84 \\
7\end{array}$ & 63 & .006 & 7.305 & 2,566 & 2.178 & 12,432 \\
\hline & $\begin{array}{c}\text { Equal } \\
\text { variances not } \\
\text { assumed }\end{array}$ & & & $\begin{array}{r}2,83 \\
3\end{array}$ & $\begin{array}{r}56.50 \\
9\end{array}$ & .006 & 7.305 & 2,578 & 2,141 & 12,469 \\
\hline
\end{tabular}


Based on the independent sample t-test output above, it can be seen that the significance value is $0.006<0.05$. This means that Ho is rejected and $\mathrm{Ha}$ is accepted. So it can be concluded that there is an effect of the STEM-based PBL learning model on creative thinking skills in fifth-grade elementary school learning.

\section{DISCUSSION}

STEM-based project-based learning research needs to be done as a learning innovation in welcoming the 5.0 industrial revolution. Research related to STEM is not the first time research has been conducted. Previously, education observers had done a lot of this research. The results of Carlisle and Weaver's research (2018) conclude that the implementation of the STEM approach can increase students' learning motivation. By applying the STEM approach in learning, students can complete the given project on their own accord. This has an impact on increasing the learning independence of students (Capraro, et al, 2016). In addition, implementing STEM-based learning can indirectly train students in integrating science, technology, engineering, and mathematics in problem solving and theoretical concepts with the real world. Creative thinking skills can be developed with the mathematical aspects of the STEM approach. In mathematical concepts that include logic and reasoning can train students to think logically and creatively. Based on these facts, the researcher believes that the STEMbased PBL learning model implemented in mathematics learning can improve students' creative thinking skills.

In this study, the STEM-based PBL learning model used mathematics educational games as the implementation of technology in learning. The game is given at the beginning of learning and students are asked to solve puzzles in the games. Students collaborate with their group members to complete challenges as projects in learning. This is very motivating for students in learning. Based on the results of observations during the learning process, students looked enthusiastic in participating in learning and completing projects. This indirectly proves that by applying the STEMbased PBL model, students are motivated to participate in learning. The research results by Nurfaadhilah \& Zubaidah (2018) conclude that there was an increase in mathematics 
learning outcomes by applying similar learning. In line with this research, Margot, KC \& Kettler, T (2019) stated that the application of STEM in mathematics learning can increase students' interest in learning.

Nadelson, L. S, et al (2013) also conducted STEM research in elementary schools. In their research, STEM is implemented with an inquiry learning model. STEM-based learning can train students to find learning concepts independently. This research was also conducted in elementary schools which differentiated the learning model used. In this study, STEM-based PBL affects students' creative thinking.

Mathematics learning can optimize students' creative thinking skills (Swanewi, 2019). Creative thinking skills train students to be able to find various solutions to the contextual problems they encounter. Students can find new ideas as solutions and can find solutions from other points of view. This kind of ability is very important to be developed as a 21st-century competency. Model The results of this study have supported the research hypothesis that STEM-based PBL learning has a significant effect on improving students' creative thinking skills. In addition, implementing STEMbased PBL can motivate students in learning mathematics. Chesky \& Wolfmeyer (2015) stated that by implementing STEM learning, mathematics learning outcomes can be increased. Internal and external factors that affect mathematics learning outcomes can be maximized by implementing STEM-based CTL learning.

\section{CONCLUSION}

Based on the analysis of research data, it can be concluded that there is an effect of the STEM-based PBL (Project-based Learning) learning model on students' creative thinking skills in elementary school fifth-grade mathematics learning. The STEM-based PBL learning model can be implemented in elementary mathematics learning. The STEM-based PBL learning model is recommended for elementary school teachers to apply the learning model to mathematics learning.

Suggestions for further researchers are expected to be able to conduct similar research for other elementary and secondary learning. In addition, based on observations during the learning process, students looked very enthusiastic in participating in learning. It is hoped that further researchers can examine the effect of the STEM-based PBL learning model on students' learning motivation. 


\section{THANK YOU NOTE}

The researcher would like to thank SDN 225 Palembang for providing convenience in research and data collection. To the University of PGRI Palembang who provided facilities and became a sponsor in this research. Thanks also to the Postgraduate lecturers at the State University of Jakarta, the Basic Education Study Program, who became partners in this research.

\section{REFERENCES}

Aldabbus, S. 2018. Project-based learning: Implementation \& challenges. International Journal of Education, Learning and Development, 6(3), 71-79.

Association of American Universities. 2013. Framework for systemic change in undergraduate STEM teaching and learning. Diambil dari https://www.aau.edu/sites/default/files/STEM\%20Scholarship/AAU_Framework .pdf

Carlisle, D.L., \& Weaver, G.C. 2018. STEM education centers: catalyzing the improvement of undergraduate STEM education. International Journal of STEM Ed 5(47), 1-21

Capraro, M. M., Whitfield, J. G., Etchells, M. J., Robert M., \& Capraro. (2016). A companion to interdisciplinary STEM project-based learning: For educators by educators (second edition). Rotterdam: Sense Publishers.

Chesky, N. Z. \& Wolfmeyer, M. R. 2015. Philosophy of STEM education: A critical investigation. New York: Palgrave Macmillan.

Chiang, C. L., \& Lee, H. 2016. The effect of project-based learning on learning motivation and problem-solving ability of vocational high school students. International Journal of Information and Education Technology, 6(9), 709-712.

Hidayat, W. \& Veny Triyana Andika Sari. 2019. Kemampuan berpikir kritis matematis dan adversity quotient siswa SMP. Jurnal Elemen, 5(2), 242-252.

Kristanti, Y. D., Subiki, \& Handayani, R. D. 2016. Model pembelajaran berbasis proyek (project-based learning model) pada pembelajaran fisika di SMA. Jurnal Pembelajaran Fisika, 5(2), 122-128. 
Margot, K. C., \& Kettler, T. 2019. Teachers' perception of STEM integration and education: A systematic literature review. International Journal of STEM Education, 6(2).

Mawardhiyah, K., \& Manoy, J. T. 2018. Literasi matematika siswa SMP dalam menyelesaikan soal PISA berdasarkan adversity quotient. MATHEdunesa, 7(3), $638-643$.

Nafiah, Y. N., \& Suyanto, W. 2014. Penerapan model problem-based learning untuk meningkatkan keterampilan berpikir kritis dan hasil belajar siswa. Jurnal Pendidikan Vokasi, 4(1), 125-143.

Nadelson, L. S., Callahan, J., Pyke, P., Hay, A., Dance, M., \& Pfiester, J. 2013. Teacher STEM perception and preparation: Inquiry-based STEM professional development for elementary teachers. The Journal of Educational Research, 106(2), 157-168.

Nilasari, N. T. \& Anggreini, D. 2019. Kemampuan literasi matematika siswa dalam menyelesaikan soal PISA ditinjau dari adversity quotient. Jurnal Elemen, 5(2), 206-219.

Nurfadhilah \& Zubaidah Amir MZ. 2018. Kemampuan penalaran matematis melalui pembelajaran contextual teaching and learning (CTL) pada siswa SMP. Jurnal Elemen, 4(2), 171-182.

Redkar, S. 2012. Teaching advanced vehicle dynamics using a project-based learning (PBL) approach. Journal of STEM Education: Innovations and Research, 13(3), 17-29.

Sudiarta, I. G. P., \& Widana, I. W. 2019. Increasing mathematical proficiency and studentscharacter: Lesson from the implementation of blended learning in junior high school in Bali. IOP Conf. Series: Journal of Physics: Conf. Series1317 (2019) 012118.

Swandewi, N.L.P., Gita, I.N., \& Suarsana, I.M. 2019. Pengaruh model quantum learning berbasis masalah kontekstual terhadap kemampuan berpikir kreatif siswa SMA. Jurnal Elemen, 5(1), 31-42.

Wahyu, R. 2016. Implementasi model project-based learning (PJBL) ditinjau dari penerapan Kurikulum 2013. Teknoscienza, 1(1), 50-62. 
Widana, I. W. 2020. The effect of digital literacy on the ability of teachers to develop HOTSbased assessment. Journal of Physics: Conference Series 1503(2020) 012045 .

Zhou, A., Kolmos, A., Nielsen, \& Frederik, D. 2012. A problem and project-based learning (PBL) approach to motivate group creativity in engineering education. International Journal of Engineering Education, 28(1), 3-16. 